\title{
Ayurvedic Management Successfully Reduces Dose of L-Dopa and Remission of Symptoms in Parkinson's Disease - (A Case Report)
}

\author{
C. K. Prathibha", Rakhi Binth Salim, K. Parameswaran Namboothiri and P. V. Anandaraman \\ Department of Panchakarma, Amrita School of Ayurveda, Amrita Viswa Vidyapeetham, \\ Amritapuri-690525, Kerala, India; ck@ay.amrita.edu
}

\begin{abstract}
Background and Aim: Parkinson's Disease (PD) is a neurodegenerative condition of motor nervous system. The symptoms of PD are similar to KampaVata (a disease of Vata Dosha) such as Karapadatala kampa (tremors in hands and foot), Dehabhramana (postural instability), Nidrabhagna (insomnia) and Matiksheena (dementia) referred by Ayurvedic classics. The most effective management of PD in Allopathic system is dopamine replacement therapy but long-term use of L-Dopa is associated with motor complications. Available medications for PD provides only symptomatic relief and there is no treatment proven to cure the disease or delay its progression. The present case report is a known case of young onset asymmetric Parkinsonism who was on 700mg L-Dopa, managed with Ayurveda therapies. The line of treatment included Vatanulomana (pacifying morbid VataDosa), Srotoshodhana (clearing of the obstructed bodychannels) and Rasayana (rejuvenation). Management and results: It included both internal and external Ayurveda therapies. Therapies were performed every year for around 20 days in 3 consecutive years. The assessment was done by Parkinson's disease questionnaire 39 and Schwab and England Activities of daily Living scale. Reduction in the dose of L-Dopa, improvement in tremor, bradykinesia, rigidity, regaining the perception of taste and smell was observed at the end of 3 years of treatment. Conclusion: The dose of L-Dopa was reduced from $700 \mathrm{mg}$ to $100 \mathrm{mg} /$ day and the quality of life improved.
\end{abstract}

Keywords: Abhyanga, Ayurveda, Kampavata, Panchakarma, Shirodhara, Srotoshodhana

Abbreviations: PD- Parkinson's disease

\section{Highlights of the Findings}

- Presentations of Parkinson's disease is similar to Kampa vata explained in Ayurveda and can be effectively managed.

- Regular Ayurveda medications can reduce the dose of L-Dopa and can improve the quality of life of Parkinson's patients.

- PDQ 39 and Schwab and England Activities of daily Living scales are reliable and easy applicable assessment tools.

- Shirodhara, Kashayadhara, Abhyanga, Pindasweda are some of the effective Ayurveda measures in Parkinson's disease.

\section{Introduction}

$\mathrm{PD}$ is a progressive neurodegenerative condition of motor nervous system. Approximately it occurs as a result of the progressive loss of Dopamine producing cells in a region of brain called the substantia nigra with a prevalence rate of 160 cases per $1,00,000$ population ${ }^{1}$. The first clinical sign occurs when about $60 \%$ of the dopamine-producing cells in the substantia nigra have degenerated. The condition is characterized by motor symptoms like tremor, rigidity,

*Author for correspondence

Article Received on: 20.01.2020

Revised on: 23.09.2020

Accepted on: 27.01.2021 
and bradykinesia, and non-motor symptoms including problems with mood, sleep and memory. Similar is the presentation of the disease KampaVata narrated in Ayurveda classical texts. The line of treatment includes Vatanulomana (pacifying morbid Vata Dosha), Srotoshodhana (clearing of the obstructed body channels) and Rasayana (rejuvenation) ${ }^{2}$. The present case report consist of a young onset asymmetric Parkinsonism treated on the above lines.

\section{Case Report}

A 58-year-old businessman, diagnosed with a case of young onset asymmetric Parkinsonism (PD) came to Panchakarma OPD of Amrita School of Ayurveda and hospital, Vallikkavu, Kollam, Kerala, India, 3 years ago. According to his statement, he started with the symptoms 15 years back. He was diagnosed as Young onset asymmetric PD at the age of 40.15 years ago, his presentations included slowing of daily routine activities, reduced arm swing especially on left hand and vague ache over left upper and lower limb. He has been under L-Dopa treatment since then. But in due course of time, the disease progressed and the dose of L-Dopa was increased from 100 to $700 \mathrm{mg}$ /day along with other supportive medications.

The patient was normal when he entered Out Patients Department (OPD) of our hospital 3 years ago. As per patient's words he was under high dose of L-Dopa, which temporarily arrests the tremors. Also, he was under anti-depressive and anti-convulsive drugs. On taking the medicines, the tremor was temporarily arrested for the next two hours and could do his routine works, but his mental status was altered due to the high dose. After two hours, same condition relapses. He also revealed familial history of the disease as his father had suffered with this disease at the age of 60 . His complaints included imbalance, slowing of all activities, tremors in both hands while eating food, unable to button the shirt, loss of appetite, and general debility. He also complained about mood swings, sleep disturbances like day sleep and sleepless nights. On examination, festinate gait, stooped posture, expressionless face, reduced eye blinking and slow speech were observed. Hypertonia of right hand was present on motor examination. Muscle power was Grade-3 in upper limb. Cranial nerve examinations revealed neurological deficits in Olfactory and Glossopharyngeal nerves.
The finger nose test for co-ordination was positive. The Parkinson's disease questionnaire $39^{3}$ (PDQ 39) the Scale for assessing the quality of life showed a score of 162 . Schwab and England Activities of daily Living ${ }^{4}$ Scale score was $30 \%$. The L-Dopa dose was $700 \mathrm{mg} /$ day.

\section{Treatments}

The patient was admitted in the IPD of the hospital and the oral medications administered were Balāsaireyakadi Kashaya, Varunitaila, Siddhamakaradhwaja, Aswagandha rishta, Mahabhutaravaghrita, Manasa mitra vataka in differ ent combinations. .External Ayurveda therapies included Kashaya Dhāra (Pouring of lukewarm decoction of medicated drugs over the whole body), Sarvanga Abhyanga (Whole body massage with oil), ShiroPichu (Medicated herbal powder mixed with medicated oil is placed over the patient's vertex for a prescribed duration), Kaya seka (Pouring of warm medicated oil on to the body uniformly followed by massage), Churna Pinda Sweda (Sudation therapy with boluses of medicinal powders), Shirodhara (Gentle pouring of liquids over the forehead for a prescribed duration). He was treated in the hospital for around 20 days every year and was advised to continue the internal medicines. He was reviewed every 2 months till his second admission to the hospital the next year. As an inpatient the same protocol was followed. Again, he was admitted for the third course of treatment after a year.

\section{Outcome Measures}

Assessments were done every year after the treatment (Table 1). Improvements in symptoms, P.D.Q.39 Scale and Shwab and England activities of daily living were used as the outcome measures. The assessments were based on the patient's perception.

\section{Discussion}

KampaVata is characterized by symptoms such as Karapadatala Kampa (tremors in hands and legs), DehaBhramana (postural instability), Nidrabhanga (insomnia) Matiksheena (dementia) ${ }^{5}$ and also the symptoms of Vatavyadhi (morbid Vata Dosha) like Sthambha (rigidity), Cheshtahani (slowness of the movement), Vinamana (flexed posture), Vakvikriti (speech disorders) etc. These presentations are similar to Parkinsonism. It is also known by the term Vepathu ${ }^{6}$ (shaking). The pathology of KampaVata is VataAvarana (covering of morbid VataDosa by morbid KaphaDosa). 


\begin{tabular}{|c|c|c|c|c|c|c|}
\hline 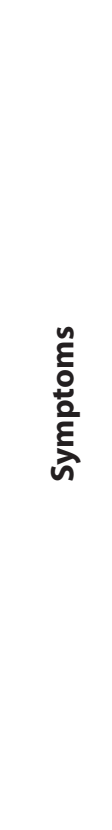 & 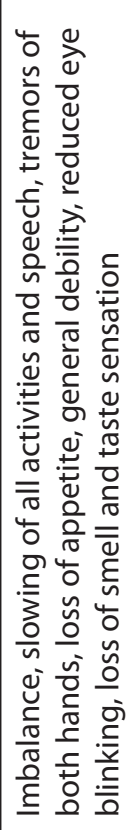 & 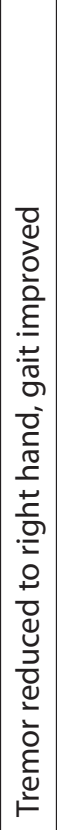 & 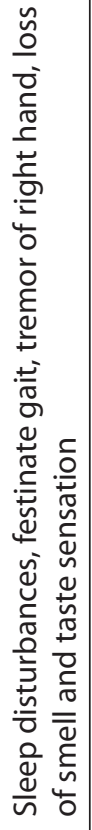 & 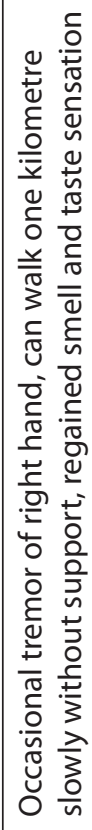 & 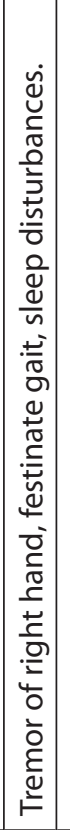 & 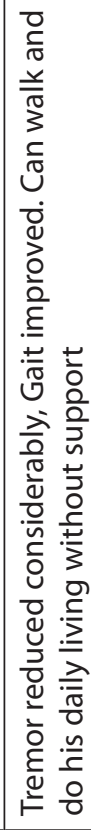 \\
\hline 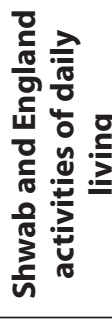 & 。ें & 今̊̀ & 品 & $\stackrel{\circ}{\circ}$ & ํำ & ઠें \\
\hline 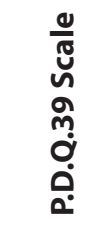 & గె & 옴 & $\stackrel{\circ}{\stackrel{n}{n}}$ & $\stackrel{\llcorner}{\llcorner}$ & $\stackrel{\sim}{\sim}$ & $\underset{\Xi}{ \pm}$ \\
\hline 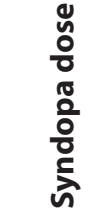 & $\begin{array}{l}\text { ते } \\
\text { oे } \\
\text { ठे } \\
\text { ठ̀ }\end{array}$ & 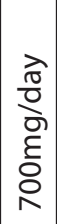 & $\begin{array}{l}\frac{\widehat{\pi}}{0} \\
\text { oे } \\
\text { हे } \\
\text { के }\end{array}$ & 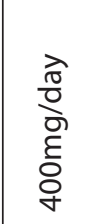 & 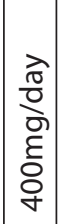 & $\begin{array}{l}\text { ते } \\
\frac{0}{0} \\
\text { हे } \\
\text { 음 }\end{array}$ \\
\hline 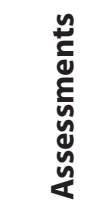 & $\underset{\infty}{5}$ & 5 & $\stackrel{\leftarrow}{\infty}$ & $\frac{5}{2}$ & 5 & $\frac{5}{2}$ \\
\hline$\frac{\boldsymbol{y}}{\sqrt{d}}$ & 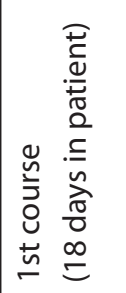 & & 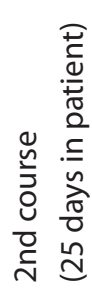 & & 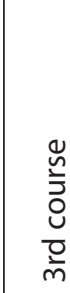 & 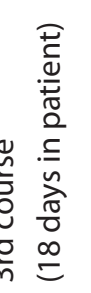 \\
\hline
\end{tabular}

This pathology can present with symptoms like Gatisanga, (obstruction of movements of the body by morbid Dosa), Vakswaragraha (difficulty to speak), Gurugātrata (heaviness), Stambhana (stiffness) and Kampanam (tremor) ${ }^{7}$. The resultant of VataĀvarana (covering of morbid Vatadosha by morbid KaphaDosa) is Dhatukshaya (depletion of tissues). Further when this pathology settled in Masthishkya (brain cells), it leads to KampaVata (Vitiation of morbid VataDosa). After considering the pathogenesis, the treatment is planned as to advocate Srotoshodhana (clearing the channels), Vatanulomana (reducing the morbid VataDosa) and Rasayana (rejuvenating therapy). Treatments like Swedana (sweating), Abhyanga, (massage), Anuvasanabasti, (oil enema)) Niruhabasti, (decoction enema), Sirobasti, (holding oil on head for specific period), Virechana (purgation) and Shamanaushadhi (Alleviating medicines) ${ }^{8}$ are suitable in the management of KampaVata. The whole protocol was aimed at correcting VataDosa (morbid Vata).

Sarvangadhara (pouring medicated liquids over whole body) is a type of Swedana (sweating) wherein disease specific medicated decoctions are poured over the whole body from a specific height. It is Sramahara, (relieves tiredness), Anilahara, (reduces morbid VataDosa), Agniprasādaka (improves metabolism), and Rujapaha (reduces pain) $)^{9}$. The same is also responsible for increase in circulation and thus improving the nourishment to different bodily tissues. Moreover, Manas (mind) and Twak (skin) are very closely related, hence can influence the action of the other ${ }^{10}$. Thus a drug which influences the skin can have simultaneous excitatory or relaxative effect on the mind and even the sense organs.

Shirodhara (pouring medicated liquids over body from particular height over the forehead) has showed highly significant relief on sleeplessness, distress, sleep time, sleep quality and freshness after awakening, in patients of stress induced chronic insomnia. Medicines poured from a particular height may produce some amount of kinetic energy which stimulates nerves, tactile and thermo receptors ${ }^{11}$. This is due to the activation of brainstem, and frontal lobe areas of brain. It causes release of endorphins, serotonin, enzymes which has anxiolytic effect. It reduced the level of plasma noradrenalin and urinary serotonin excretion. It also decreased the rate of breathing and heart rate. Hence Shirodhara (pouring medicated liquids over body) was effective in improving the sleep as well as activating at the level of brain so that walking capacity and coordination could be better in the patient.

Abhyanga (body massage with medicated oil) is a procedure practiced daily for maintaining health in 
healthy and also advocated in ill-health ${ }^{12}$. It prolongs aging, reduces tiredness, and improves eyesight, sleep and strength $^{13}$. Oils used in Abhyanga will reach up to different Dhatus $^{14}$ when it is applied for sufficient time. The drug used for Abhyanga gets absorbed through the skin and can act over the skin, which is a seat of Vata. Abhyanga (massage) stimulates the nervous system and can act on physical and emotional well-being by normalizing the Atipravrutti of Vata ${ }^{15}$ (increased morbid VataDosa). It also improves lymphatic drainage and thereby increases neurotransmitters like serotonin which is low in depression, schizophrenia etc conditions ${ }^{16}$. Absorption through the skin can be enhanced by suspending the drug in an oily vehicle and rubbing the resulting preparation into the skin (Goodman \& Gilman - 1996). Hence, topical drugs which are lipid soluble easily enter into papillary region of dermis, and may enter into capillary circulation through dermis, and finally may enter into systemic circulation ${ }^{17}$.

ShiroPichu is a procedure of application of medicine over the bregma/anterior fontanelle, the area which facilitates easy absorption of medicine ${ }^{18}$. It has a very good calming effect over mind ${ }^{19}$.

Churna Pinda Sweda being Snigdha (oily) and UshnaVirya (hot potency) corrects the deranged Vâta (morbid Vata Dosha) and Kapha Dosha (morbid kaphaDosa) and relieves stiffness. It not only relieves stiffness, but also clears blocking of passages (Srotorodha). As Swedana (sudation therapy) has the opposite qualities to that of Vāta (morbid vataDosa) and Kapha (morbid kaphaDosa), thereby producing a palliative effect on them and the Srotas (channel) is becoming normal. It is well known that unless there is a Srotodushti (obstruction to the channels) there is no disease. Thus, Swedana (sudation therapy) clears the Srotho dushti or Sanga (obstruction of channels). In other words, by contact of bearable warmth, the area in contact gets more circulation. The lumina of the contracted body architecture get smoother and wider, rendering a stiff entity to become smooth and relieves a variety of obstructions ${ }^{20}$.

The drugs used internally are of Katu (acrid) and Tikta rasa (bitter taste), Laghu, Ruksha Guna (light and dry properties), Katu Vipaka (acrid potency), KaphaVatahara (reducing morbid Kapha and Vata), Balya (strengthening), Bruhmana (nourishing) and Vrishya Karma ${ }^{21}$ (Rejuvenating). Hence these are of Srotoshodhaka (clearing the channels) in nature and is having VataKaphahara (reducing morbid Kapha and Vata) property which can correct the pathology of AvaranaVāta (obstructed morbid Vāta).
The main ingredient of decoction used internally is Bala (Sidacordifolia). It is VataPittaShaamaka (reducing morbid Vata and Pitta), Balya (strengthening), Bruhmana (nourishing) and Ojovardhaka (improves immunity). It is Bruhmana (nourishing), Balya (improves strength) and increases energy $y^{22}$ because of the principle ephedrine. The drug is generally considered as a nervine tonic.

Mahabhutarava Ghrita (medicated ghee) is indicated mainly in ManasikaVikaras (mental disorders) ${ }^{23}$. The ingredients of Mahabhutarava Ghrita are Medhya (improves intellect) and it is Srotoshodhaka (cleaning the channels) in nature. Research studies conducted on Yashtimadhu (Glycyrrhiza glabra Linn) which is an ingredient of this ghrita reveals that it has rejuvenating, anticonvulsant effects, memory enhancing activity, antioxidant potential activity, etc. ${ }^{24}$ Ghrita (ghee) itself acts as Medhya (improves intellect), Bruhmana (nourishing), Rasāyana (rejuvenating) and Vatanulomaka (downward movement of morbid VataDosa). Hence, it may act against nerve degeneration which is the main reason for this disease. Also, ghee preparations readily enter the brain crossing the blood brain barrier and act on target $\operatorname{organ}^{25}$.

\section{Conclusion}

The case study presented suggested that an integrated approach will be effective in managing Parkinson's disease. Ayurveda medications can arrest the progress and regress the dose of L-Dopa. The rate of progression and its course varies according to an individual. The disability of Parkinson's disease can be decreased with early Ayurveda treatment by reducing the symptoms, improving the functional movements and thereby the quality of life. Since it is a chronic condition it requires long term treatment. Further research studies incorporated with scientific methods will open a new challenge in the treatment of Parkinsonism.

\section{References}

1. Savant NS, et al. Behind the mask, a study on the clinical course, psychopathology and impact on quality of life in idiopathic Parkinson's disease. Indian J Psychiatr. 2004; 354-60.

2. Acharya Y. Charaka Samhita with ayurveda Deepika commentary by Chakrapanidatta, Chowkhamba Krisnadas Academy, 2nd edition, Varanasi. Chikitsa Sthana 28; 2006.

3. Peto V, Jenkinson C, Fitzpatrick R, Greenhall R. The development and validation of a short measure of functioning and well-being for individuals with 
Parkinson's disease. Qual Life Res. 1995; 4(3):241-8. https://doi.org/10.1007/BF02260863. PMid:7613534

4. Kompoliti K, Metman VL. Encyclopedia of movement disorders. Elsevier Publications; 2010. p. 99-100

5. Shastry RD, Basvarajiyam B. Chawkhamba Sanskrit Series, Varanasi, Chapter 6; 1987.

6. Agnivesha. Charaka Samhita with ayurveda Deepika commentary by Charapanidatta, ChowkhambaKris hnadas Academy, 2nd edition, Varanasi, Sutra Sthana 20, Sloke no. 11; 2006.

7. Acharya Y. Charaka Samhita with ayurveda Deepika commentary of Chakrapanidatta, ChowkhambaKri snadas Academy, 2nd edition, Varanasi. Chikitsa Sthana Chapter 28; 2006. p. 223, 224, 228.

8. Lalji JS. Vangasena Samhita. Khemraj Sri Krishnadas Publication, Mumbai, Vatavyadhiadhikara; 2003.

9. Acharya Y. Sushruta Samhita with Nibandha Sangraha, ChaukhambhaOrientalia, 8th Edition, Chikitsasthana; 2005. p. 24:31.

10. Acharya Y. Charaka Samhita with ayurveda Deepika commentary of Chakrapanidatta, Chowkha mba Krisnadas Academy, 2nd edition, Varanasi, Sutra sthana; 2006. p. 11:38.

11. Haramohan M, Mahapatra AK, Maharana L, Singh SK. Therapeutic efficacy and mechanism of action of Ayurvedic Shirodhara: An evidence-based review. World Journal of Ayurveda Science. 2017; 2(1).

12. Acharya Y. Charaka Samhita with ayurveda Deepika commentary of Chakrapanidatta, Chowkhamba Kris nadas Academy, 2nd edition, Varanasi, Sutrastana; 2006. p. 5:87.

13. Acharya Y. Charaka Samhita with ayurveda Deepika commentary of Chakrapanidatta, Chowkhamba Krisnadas Academy,2ndedition, Varanasi,Sutrastana; 2006. p. 2:8.

14. Acharya Y.Sushruta samhita with NibandhaSangraha, ChaukhambhaOrientalia,8thedition,ChikitsaSthana; 2005. p. 24:3.
15. Acharya Y. Charaka Samhita with ayurveda Deepika commentary of Chakrapanidatta, ChowkhambaKris nadas Academy, 2nd edition, Varanasi, Sutrastana; 2006. p. 5:87.

16. Agnihothri VK, Vijaykumar, Sharma R. Therapeutic significance of Shiroabhyanga- A review. Internat ional Journal of Research in Ayurveda and Pharmacy. 2015; 6(6). https://doi.org/10.7897/2277-4343.066135

17. Agnihothri VK, Vijaykumar, Sharma R. Therapeutic significance of Shiroabhyanga-A review. Internat ional Journal of Research in Ayurveda and Pharmacy. 2015; 6(6). https://doi.org/10.7897/2277-4343.066135

18. Shripathyadiga, Adiga RS. The concept of Thalam in Ayurveda: An analytical approach. Journal of Ayur veda and Holistic Medicine. 2017; 5(4).

19. Raj K. A conceptual study of Shiropichu in the mana gment of Shirashoola. International Ayurvedic Medical Journal. 2017; 5(5).

20. Gaurav M, Muralidhar P. Clinical study to evaluate the effect of modified Choornapindasveda in the management of katigraha (lumbago). International Journal of Research in Ayurveda and Pharmacy. 2017; 8(4). https://doi.org/10.7897/2277-4343.084228

21. Sitaram B. Bhavaprakasha of Bhavamisra, Chaukham bhaOrientalia, Varanasi; 2006. 1. p. 265-6.

22. Anonymous. Wealth of India. Dictionary of Indian raw material and industrial products, New Delhi, Publication and information directorate CSIR. 1988; p.323-4.

23. Vaidya HP. Ashtanga hrudaya with Sarvangasundari commentary by Hemadri, ChoukhambaKrishnadas Academy, 2nd edition, Varanasi, Uttarasthana; 2006. p. 5.

24. Shashikant MP, Bhuesh RP. Phyto-pharmacological perspective of Yashtimadhu (Glycyrrhizaglabra Linn.) A review. Int J Pharmaceut Biol Arch. 2013; 4(5):833-41.

25. Neetu Singh, Chaudhary A. A comparative review study of Snehakalpana (paka)vis-à-vis lipo some. Ayu. 2011; 321:103-8. https://doi.org/10.4103 10974-8520.85740. PMid:22131767 PMCid:PMC321 5405 